\title{
APPLICATION OF FUZZY LOGIC TO ASSESS BANKS' CREDIT RISK
}

\author{
M.I. Ozerova, ozerovam@rambler.ru, \\ I.E. Zhigalov, ikgij@vlsu.ru \\ Vladimir State University named after Alexander and Nicolay Stoletovs, Vladimir, \\ Russian Federation
}

\begin{abstract}
The banking system is a constantly evolving system. The information environment of the bank is growing, the volumes of processed information are increasing due to the growth of users and banking products. To reduce risks, banks make a financial assessment of the situation of individuals and legal entities. The aim of the work is to develop fuzzy multi-connected models designed to predict the receipt of a positive or negative decision to receive a banking product. The decision is made based on scoring. Scoring consists in assigning points for completing a certain questionnaire developed by underwriters of credit risk assessors. Based on the results of the points gained, the system automatically makes a decision on approving or refusing to issue a loan. Different banks have different scoring models. Purpose of the study. The paper considers the use of fuzzy models for making a decision by a bank to issue a banking product that implements the concept of "soft computing". Methods. The use of fuzzy logic methods in credit scoring is not new, but it is not widely used in practice because it is expensive to integrate into existing systems. Each bank uses its own indicators of the client's financial reliability in scoring. Most of the indicators in banks are the same, but when deciding to issue different banking products, they have different numerical values. The data of the standard scoring methodology of a real bank were taken as the initial data. To predict a bank's decision to issue a banking product to a client, a fuzzy model was applied, production rules were proposed, and membership functions were determined. The model focused on the simultaneous processing of incoming data from multiple clients and for different banks and different scoring models. Results. The developed mathematical model for assessing the client's rating and predicting the decision to receive a banking product based on the fuzzy inference rule. The obtained results are proposed to be used in a multi-banking web-oriented system of providing banking products to corporate clients.
\end{abstract}

Keywords: mathematical models, credit rating, scoring, fuzzy logic.

\section{Introduction}

The work of banks is associated with lending activities, investment of funds, and therefore in their activities should take into account the risks of loss of funds. To this end, banks regularly identify significant risks and analyze the causes of their occurrence. To reduce risks, banks make a financial assessment of the situation of individuals and legal entities. Deciding on the basis of which method to build a scoring system that determines the rating is a difficult problem, since the quality of the solution depends both on the model and on the quality of the available data, their noisiness and heterogeneity. The bank evaluates the financial position of the client, first, based on the information available to the bank about the client and, secondly, by requesting additional information on income from the client himself. Further, the data is processed according to its own algorithm adopted in each bank and a customer reliability rating is obtained. The rating is an aggregated assessment of the client's financial position. The rating model for assessing credit risk is quite popular and consists of a set of quantitative and qualitative characteristics of the client. These characteristics are checked, analyzed by the bank and they determine the creditworthiness of the client.

To conduct an adequate analysis of the client's financial position in terms of qualitative characteristics, reliable, from the point of view of the bank, sources of information are used [1]. These are accounting data, data from the tax service, documents received from various departments of the bank. Nowadays, it has become popular to analyze customer data posted on the Internet, media, and social networks.

For quantitative analysis, the data provided by the client in the financial statements is used.

It should be noted that each bank uses its own methodology for calculating the customer's reliability rating and assessing his financial position. 


\section{Domain analysis}

One of the most popular methods for determining the credit rating based on the summation of points [2]. Quantitative and qualitative characteristics, according to expert judgment, are determined in the form of points. The score based on a rating scale, from highest (good) to lowest (bad). To determine the final indicator of the client's financial position, the arithmetic mean of the points considered based on the sum of all criteria, quantitative and qualitative characteristics.

For example, there is a group of indicators of the bank XXX: quantitative, qualitative and corrective characteristics of the client $\left(X_{i}\right)$. Each group is characterized by $n$ characteristics.

For each group, the average score of the analyzed group is calculated, and is calculated using the following formula:

$$
X_{\text {average }}=\frac{\sum\left(X_{1}+X_{2}+X_{n}\right)}{\sum X_{n}},
$$

where $X_{\text {average }}$ - the average score of the characteristics of the analyzed subgroup; $X_{n}$ - the analyzed parameter of the characteristics of the subgroup; $X_{1}$ - subgroup indicator; $X_{2}$ - a subgroup indicator.

For each subgroup, the total number of points of quantitative, qualitative parameters and indicators calculated which adjust the client's credit rating. The client's credit rating determined by the formula:

$$
R=\sum X_{\text {1average }}+\sum X_{\text {2average }}+\sum X_{3 \text { average }},
$$

where $X_{\text {laverage }}$ - the average score of the quality parameters of the Client; $X_{\text {2average }}$ - the average score of the quantitative parameters of the Client; $X_{3 \text { average }}$ - the average score of the correcting parameters.

Based on the totality of the assigned points, taking into account the established intervals of the scoring values, the final credit rating of the client $(\mathrm{R})$ and his financial position are determined.

The Table 1 contains a description of the client's financial position in accordance with the rating determined by the parameters of bank XXX.

\section{Compliance of the rating with the assessment of financial position}

Table 1

\begin{tabular}{|c|c|c|c|l|}
\hline $\begin{array}{c}\text { Score } \\
\text { Min }\end{array}$ & $\begin{array}{c}\text { Score } \\
\text { Max }\end{array}$ & $\begin{array}{c}\text { Rating } \\
R\end{array}$ & $\begin{array}{c}\text { Financial } \\
\text { position }\end{array}$ & \multicolumn{1}{|c|}{ Description } \\
\hline 0 & $<1.5$ & $\mathrm{C}$ & not satisfactory & $\begin{array}{l}\text { Low degree of creditworthiness. The main indica- } \\
\text { tors of the financial position assessed as satisfactory } \\
\text { or close to satisfactory, but their stability is ques- } \\
\text { tionable. The company has serious enough problems } \\
\text { or is at a significant risk of serious problems }\end{array}$ \\
\hline$\geq 1.5$ & $<5$ & $\mathrm{~B}$ & satisfactory & $\begin{array}{l}\text { Average degree of creditworthiness. The financial } \\
\text { position assessed as satisfactory and stable in } \\
\text { the short term. The company has no problems that } \\
\text { could lead to loss of creditworthiness }\end{array}$ \\
\hline$\geq 5.1$ & $\leq 8$ & A & high position & $\begin{array}{l}\text { High degree of creditworthiness. The financial posi- } \\
\text { tion assessed as good and stable in the long term. } \\
\text { The company has no discernible problems }\end{array}$ \\
\hline
\end{tabular}

The aim of the work is to develop fuzzy multi-connected models $[3,4]$, designed to predict the receipt of a positive or negative decision to receive a banking product, including the assessment of the credit rating of a legal entity (Client).

\section{Modeling method}

The use of fuzzy logic methods in credit scoring is not new, it is presented in works [5-8], and however, with the growth of information technologies, new opportunities for their implementation appear. Currently, neural networks and systems with fuzzy logic have proven themselves well in forecasting in the form of a fuzzy neural network [9-12]. The concept of "fuzzy set" fuzzy set, introduced by L. Zadeh in 1965 [13], admits that the characteristic function (the function of membership of an element 


\section{Управление в социально-экономических системах}

in a set) can take any values in the interval [0,1], and not only values 0 or 1 . This relation is described using the membership function $\mu \rightarrow[0,1]$. L. Zadeh proposed, by analogy with the theory of probability, to use the function [14] as a mathematical model of the linguistic uncertainty of the object [15]:

$x \in X:[10] . Y=\mu(x, B)$,

where $Y$ is the result of calculating the function, expressing the measure of uncertainty (fuzziness) for a specific object $x \in X ; \mu$ is a continuous function such that $\mu: X \rightarrow[0,1]$. In essence, the function $\mu$ determines the distribution of uncertainty on $X ; X$ - the domain of definition of the function $\mu$.

The domain of definition specified by an ordered set of values, of an arbitrary nature, called a universal set (or universe).

The support of the function $\mu(x, B)$ is the subset $w \subset X$, on which the function $\mu(x, B)$ takes on a nonzero value. The set of real numbers usually given as a universal set; $B$ - a vector of function parameters, usually numeric.

Fuzzy inference systems based on rules [16], which can be represented by the following types of production rules, containing in the right-hand sides: three types of production rules, containing in the right parts, can represent constants:

constants

$$
R^{\theta}: \text { if } x_{1} \text { is } X_{1}^{0}, x_{2} \text { is } X_{2}^{0}, \ldots, x_{m} \text { is } X_{m}^{0} \text {, then } y=c^{0},
$$

fuzzy sets

$$
R^{\theta}: \text { if } x_{1} \text { is } X_{1}^{0}, x_{2} \text { is } X_{2}^{0}, \ldots, x_{m} \text { is } X_{m}^{0} \text {, then } y \text { is } Y^{\theta},
$$

and linear equations

$$
\begin{aligned}
& R^{\theta}: \text { if } x_{1} \text { is } X_{1}^{0}, x_{2} \text { is } X_{2}^{0}, \ldots, x_{m} \text { is } X_{m}^{0}, \\
& y^{\theta}=c_{0}^{\theta}+\sum_{l=1}^{m} c_{l} x_{l},
\end{aligned}
$$

where $\theta=\overline{1, n}, l=\overline{1, m} ; \theta$ - is the rule number; $n$ - number of rules; $l$ - number of input; $m$ - number of input variables; $c^{\theta}=\left(c_{0}^{\theta}, c_{1}^{\theta}, \ldots, c_{m}^{\theta}\right)$ - vector of coefficients; $X_{l}^{\theta}, Y^{\theta}$ - fuzzy sets characterized by membership functions $X_{l}^{\theta}\left(x_{l}, d_{l}^{\theta}\right), Y^{\theta}\left(y, d^{\theta}\right)$ the shape, size and location of which depends on the vectors of parameters $d_{l}^{\theta}$ и $d^{\theta}$.

Fuzzy forecast models are calculated using the formula:

$$
y_{i}^{\theta}=f\left(X_{i}^{\theta}(k), Z_{i}^{\theta}(k) \varepsilon_{i}^{\theta}\right),
$$

where $\varepsilon_{\mathrm{i}}-$ the vector of parameters and structural elements of the fuzzy $i$-th model (rules 1,2,3).

In this case, the following conditions must be observed [17]:

1. There is at least one rule for each linguistic term of the output variable.

2. For any term of the input variable, there is at least one rule in which this term used as a prerequisite (left side of the rule). Otherwise, there is an incomplete fuzzy rule base.

To predict the bank's decision $\left(Y_{j}\right)$ to issue a banking product (BP) to the Client, apply fuzzy models like (1)-(3), with parametric and structural learning algorithms and implementing the concept of "soft computing" [18].

Let us introduce the following notation:

Qualitative parameters of the Client $X_{i}$ :

$U(k)=\left(U_{1}(k) \ldots U_{n}(k)\right)$, the variables defining $Y_{j}$, respectively: $U_{j}(k)=\left(U_{1 j}(k) \ldots U_{n j}(k)\right)$.

Quantitative indicators of the Client $Z_{i}$ :

$Z(k)=\left(Z_{1}(k) \ldots Z_{n}(k)\right)$.

The variables defining $Y_{j}$, respectively: $Z_{j}(k)=\left(Z_{1 j}(k) \ldots Z_{n j}(k)\right)$.

Indicators adjusting the Client's credit rating $\left(\varepsilon_{i}\right)$ :

$G(b)=\left(G_{1}(b) \ldots G_{n}(b)\right)$ and accordingly $G_{j}(b)=\left(G_{1 j}(b) \ldots G_{n j}(b)\right)$. 
In addition, it is necessary to take into account the type of banking product (BP) having the number $g=1, N$.

Then, according to formula (4), to predict the optimal solution $Y_{j}$ in the $b$-th bank, fuzzy models of forecasting the optimal solution $Y_{j}$ are required, we obtain the formula:

$$
\begin{aligned}
& y_{j}^{g}=f\left(U_{j}^{g}(k), Z_{j}^{g}(k) G_{j}^{g}(b) \varepsilon_{j}^{g}\right), \\
& g=1, m, j=n,
\end{aligned}
$$

where $m$ - the number of bank products; $n$ - sample length; $\varepsilon_{j}^{g}$ - a vector of parameters and structural elements of the fuzzy $\mathrm{j}$ model.

The accuracy of the forecast is the proximity of the calculated $y_{j}^{g}$ to the given $Y^{g}$ value is estimated by the value of the criterion, which is a function of the error:

$$
J\left(\varepsilon_{j}^{g}(b)\right)=\Phi\left(\varepsilon_{j}^{g}(b)\right) .
$$

Next, you need to check the fuzzy model by the condition:

$$
\begin{aligned}
& J_{i}=\frac{1}{N} \sum_{s=1}^{N}\left|y_{i}(p)-\hat{y}_{i} p\right|, \forall i=\overline{1, q}, \\
& 0 \leq J_{i} \leq 0,2 .
\end{aligned}
$$

In the process of training the model, it is possible to change the number of variables in groups, therefore, to simplify formula (5), we introduce the notation $U(k), Z(k)$ and $G_{j}(b)$ through $X_{j}$ we obtain formula:

$$
y_{j}^{g}=f\left(U_{j}^{g}\left(x_{i j}\right), Z_{j}^{g}\left(x_{i j}\right) G_{j}^{g}\left(x_{i j}\right) \varepsilon_{j}^{g}\right) .
$$

\begin{tabular}{|c|c|c|c|}
\hline $\begin{array}{l}\text { Variable } \\
\text { name }\end{array}$ & Variable label & Categories of Possible Values & $\begin{array}{l}\text { Measurement } \\
\text { scale }\end{array}$ \\
\hline \multicolumn{4}{|c|}{ Dependent variables } \\
\hline$Y_{i}$ & $\begin{array}{l}\text { Customer not receiving banking products. } \\
\text { Receipt of a banking product by a client }\end{array}$ & $\begin{array}{l}0-\text { bad } \\
1-\text { good }\end{array}$ & Nominal \\
\hline \multicolumn{4}{|c|}{ Independent variables } \\
\hline$x_{1}$ & Principal (client) region & $\begin{array}{l}0 \text { - not incl. to the register } \\
1-\text { incl. to the register }\end{array}$ & Nominal \\
\hline$x_{2}$ & $\begin{array}{l}\text { Limit of the banking product of the princi- } \\
\text { pal (client) in the given bank }\end{array}$ & $\begin{array}{l}\text { Strong. Good, Satisfactory, } \\
\text { Weak }\end{array}$ & Quantitative \\
\hline$x_{3}$ & Number of applications in this bank & $\begin{array}{l}\text { Strong. Good, Satisfactory, } \\
\text { Weak }\end{array}$ & Quantitative \\
\hline$x_{4}$ & Procurement Law & $\begin{array}{l}0-\text { not incl. to the register } \\
1-\text { incl. to the register }\end{array}$ & Nominal \\
\hline$x_{5}$ & Principal's form of ownership & $\begin{array}{l}0-\text { not incl. to the register } \\
1-\text { incl. to the register }\end{array}$ & Nominal \\
\hline$x_{j}$ & $\ldots$ & $\ldots$ & $\ldots$ \\
\hline
\end{tabular}

Table 2 shows the groups of input variables that influence the decision to provide a banking product $\left(Y_{i}\right)$.

Groups of input variables influencing the decision to provide a banking product

It should be borne in mind that each bank has individual scoring models [19], in this case we have 39 different models that are built according to these variables. Thus, passing to the new designations of the input variables $x_{i}: l=1, j=1, q=39$ where $q$ is the number of fuzzy forecast models by formula (4), we obtain $y_{j}$ :

$$
y_{j}=f_{j}\left(x_{i j}, \varepsilon_{j}\right)
$$




$$
\begin{aligned}
& R_{i}^{\theta}: \text { if } x_{1}(k) \text { is } X_{i 1}^{\theta}, x_{2}(k) \text { is } X_{i 2}^{\theta}, \ldots, x_{j}(k) \text { is } X_{i j}^{\theta}, \ldots, x_{m}(k) \text { is } X_{i m}^{\theta} ; \\
& y_{i}^{\theta}(k)=c_{i 0}^{\theta}+c_{i 1}^{\theta} x_{1}(k)+\ldots+c_{i j}^{\theta} x_{j}(k)+\ldots+c_{i m}^{\theta} x_{m}(k), \\
& \theta=\overline{1, n_{i}}, i=\overline{1, q},
\end{aligned}
$$

where $X$ - fuzzy sets described by membership functions: $X\left(x_{j}, d_{i j}^{\theta}\right)$, depending on the input variables $x_{j}$ and the parameter vectors

$$
d_{i j}^{\theta}=\left(d_{i j 1}^{\theta}, d_{i j 2}^{\theta}, \ldots, d_{i j \sigma}^{\theta}\right),
$$

where $\theta=\overline{1, n}, j=\overline{1, m}, i=\overline{1, q} ; \theta, n_{i}$ - number and number of production rules of a fuzzy model predicting the $i$-th probability indicator $y_{j} ; c_{i j}^{\theta}$ - coefficients of linear equations.

The production rules and the fuzzification operation form a fuzzy model [20], which has the following analytical form:

$$
y_{j}(k)=\sum_{\theta=1}^{n_{i}}\left(c_{i}^{\theta}\right)^{T} x_{i}^{\theta}\left(k, d_{i}^{\theta}\right)
$$

where $\left(c_{i}^{\theta}\right)^{T}=\left(c_{i 0}^{\theta}, c_{i 1}^{\theta}, \ldots, c_{i m}^{\theta}\right)$ - vector of coefficients of the linear equation of the $\theta$-th rule;

$\theta=\overline{1, n} ; \tilde{x}_{i}^{\theta}(k)=\left(\beta_{i}^{\theta}, \beta_{i}^{\theta} x_{1}(k), \ldots, \beta_{i}^{\theta} x_{m}(k)\right)$ - extended input vector of the $\theta$ th rule, containing as a multiplier a nonlinear fuzzy function of parameters $d_{i}^{\theta}$

$$
\beta^{\theta}\left(d_{i}^{\theta}\right)=\frac{W_{i}^{\theta}}{\sum_{\theta=1}^{n_{i}} W_{i}^{\theta}},
$$

where $W_{i}^{\theta}$ - the truth value of the $\theta$-th rule, equal to the product of the membership functions.

$$
W_{i}^{\theta}=X_{i}^{\theta}\left(x_{1}\right) \cdot X_{i}^{\theta}\left(x_{2}\right) \cdot \ldots \cdot X_{i}^{\theta}\left(x_{m}\right) .
$$

The vector $\varepsilon$ is refined by the identification algorithm, we indicate parametric (coefficients of linear equations $c=\left\{c_{i j}^{\theta}\right\}$, parameters $=\left\{d_{i j}^{\theta}\right\}, \theta=\overline{1, n}, j=\overline{1, m}, i=\overline{1, q}$ ) and structural elements (the number of rules $\mathrm{n}$ and the number $\mathrm{m}$ and the composition of the variables).

Getting the forecasting value $y_{j}(k)$, ncheck the accuracy of the forecast and if the value $J_{\Pi}^{r}(i)$ not lower than the permissible value $J_{\Pi}^{\partial}=0.8$ and satisfies the condition $J_{\Pi}^{r}(i) \geq J_{\Pi}^{\partial}$, then we accept.

The structure of a multiply connected fuzzy model is shown in Fig. 1.

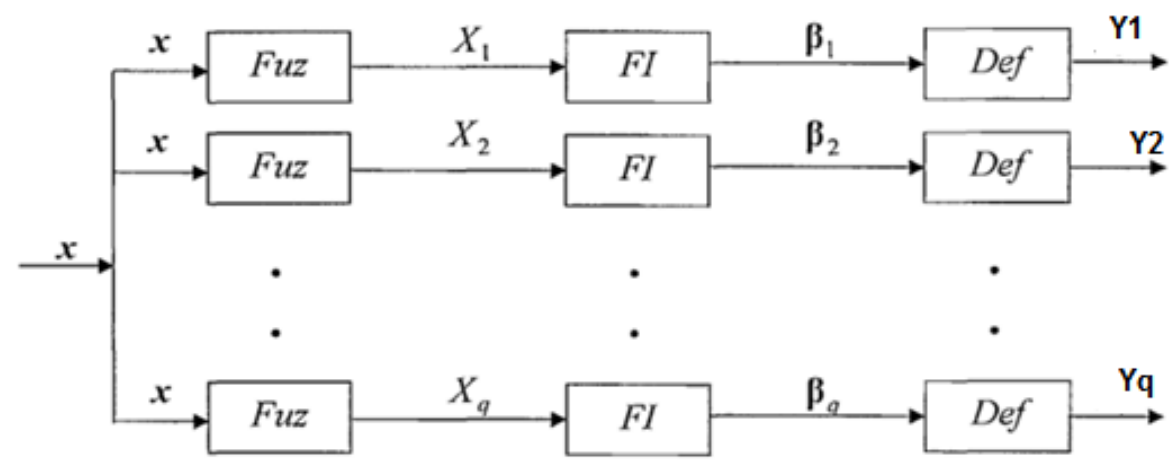

Fig. 1. Structure of a multiply connected fuzzy model

The model is focused on the simultaneous processing of incoming data from many clients and for different banks and different scoring models, so the entire space of incoming data is divided into subspaces using the FCM clustering method. The calculation was performed in the MATLAB system. Fig. 2 shows a fragment of the result of the proposed methodology in a multi-banking system. 


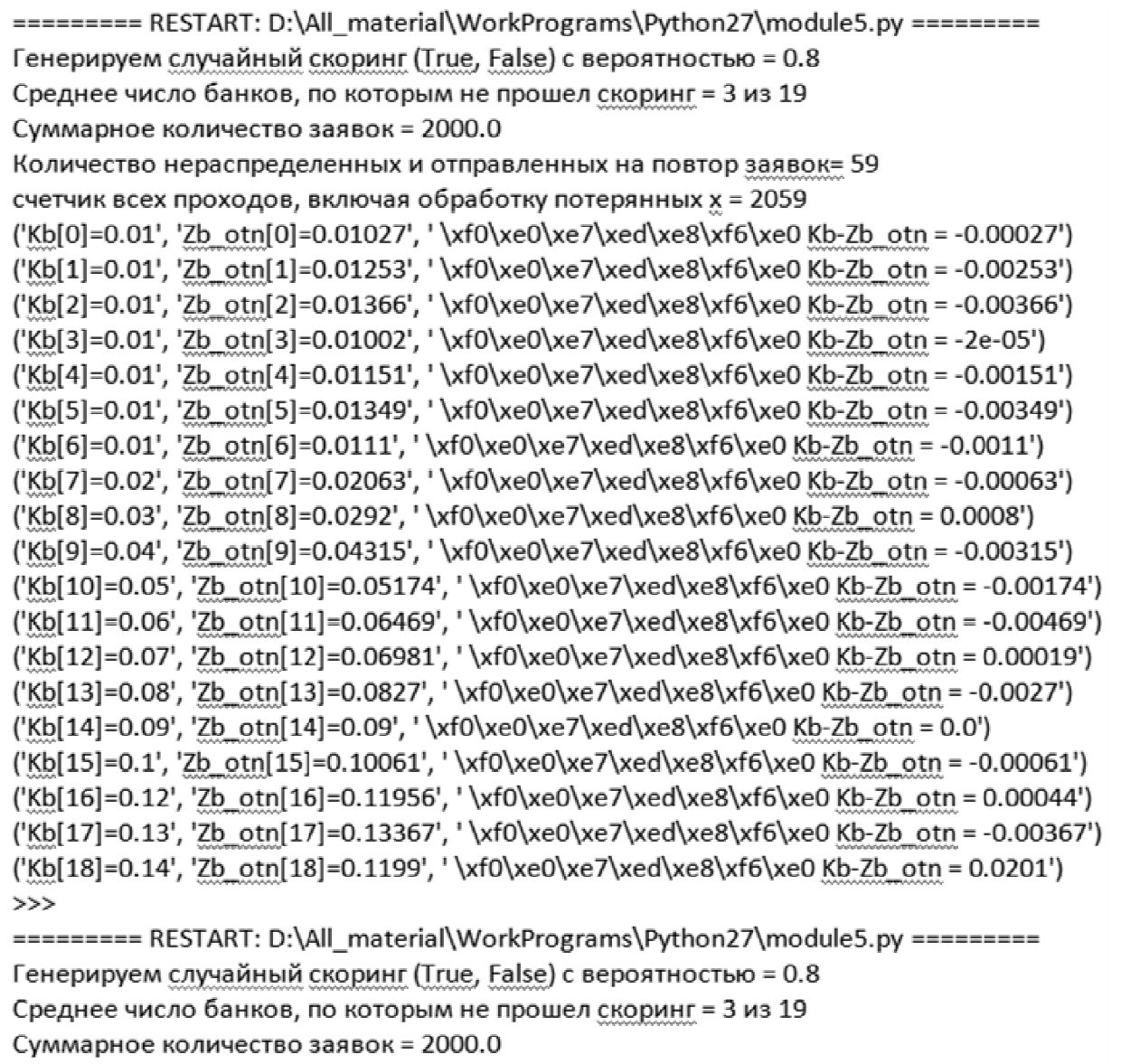

Fig. 2. A fragment of the result of the algorithm

\section{Conclusion}

To predict the customer's reliability rating, three types of fuzzy models were taken, for certain groups of customer financial indicators and the requirements of banks. For each model, production rules are proposed, membership functions are defined.

The developed mathematical model for assessing the client's rating and predicting the decision to receive a banking product based on the fuzzy inference rule made it possible to find the most acceptable conclusion. The results obtained were proposed to be used in a multi-banking web-oriented system of providing banking products to corporate clients.

\section{References}

1. Hannanova E.A. [Theoretical foundations for assessing creditworthiness]. Bulletin of Science and Education, 2016, no. 12 (24), pp. 46-48. (in Russ.)

2. Kostykova M.Yu. [Scoring model of small business lending and its improvement in the Russian Federation]. Finance and Credit, 2014, no. 15, pp. 57-64. (in Russ.)

3. Joshua Ignatius, Adel Hatami-Marbini, Amirah Rahman, Lalitha Dhamotharan, and Pegah Khoshnevis. A fuzzy decision support system for credit scoring. Neural Comput \& Applic, 2018, no. 29, pp. 921-937. DOI: 10.1007/s00521-016-2592-1

4. Gorlushkina N.N., Shin E.V. [Reengineering of the lending business process and the use of the apparatus of fuzzy sets for the classification of borrowers in the problem of credit scoring]. Online magazine "Science of Science". Economics and Management, 2015, vol. 7, no. 2, pp. 1-11. (in Russ.). Available at: https://naukovedenie.ru/PDF/82EVN215.pdf.

5. Hoffmann F., Basens B., Mues K., Van Gestel T., and Vantienen J. Derivation of descriptive and approximate fuzzy rules for credit scoring using evolutionary algorithms. European Journal of Operational Research, 2007, pp. 540-555. 


\section{Управление в социально-экономических системах}

6. Ignatius J., Khatami-Marbini A., Rahman A. et al. Support system for fuzzy decisions for credit scoring. Neural calculations and applications, 2016, pp. 1-17. DOI: 10.1007 / s00521-016-2592-1

7. Xinhui C., Zhong Q. On Consumer Credit Scoring Based on Multi-criteria Fuzzy Logic. Proc. Int. Conf. Business Intelligence and Financial Engineering, 2009, BIFE'09. IEEE, 2009, pp. 765-768.

8. Lakhsasna A., Ainon R.N., Vakh T.Yu. Modeling decisions on credit risk assessment using an optimized fuzzy classifier. International Symposium on Information Technology 2008. IEEE, 2008, vol. 1, pp. 2-8.

9. Kudinov Yu.I., Ivanchenko K.S., Kudinov I.Yu. [Development of a fuzzy system for predicting the quality of metal products]. Mechatronics, automation, control, 2008, no. 10, pp. 27-32. (in Russ.)

10. Labinsky A.Yu., Nefediev S.A., Bardulin E.N [Use of fuzzy logic and neural networks in automatic control systems]. Scientific-analytical journal Bulletin of the St. Petersburg University of the State Fire Service of the EMERCOM of Russia, 2019, no. 1, pp. 44-50. (in Russ.)

11. Pezeshki Z., Mazinani S.M. Comparison of artificial neural networks, fuzzy logic and neuro fuzzy for predicting optimization of building thermal consumption: a survey. Artif Intell, 2019, vol. 52, no. 1, pp. 495-525. DOI: 10.1007/s10462-018-9630-6

12. Xiaoying Su, Sihong Xu, Shaochuan Xu. Compound control system for coagulant dosing process based on a fuzzy cerebellar model articulation controller. Conference: 2017 36th Chinese Control Conference (CCC). IEEE, 2017, pp. 3931-3937. DOI: 10.23919/ChiCC.2017.8027972

13. Zade L. Ponyatie lingvisticheskoy peremennoy $i$ ego primenenie dlya prinyatiya priblizhennykh resheniy [The concept of a linguistic variable and its application for making approximate decisions]. Moscow, Mir Publ., 1976. 167 p.

14. Yarushkina N.G., Afanasyeva T.V., Perfilieva I.G. Integratsiya nechetkikh modeley dlya analiza vremennykh ryadov [Integration of fuzzy models for time series analysis]. Ulyanovsk, 2010. $320 \mathrm{p}$.

15. Ozerova M.I., Zhigalov I.E. Application of neuro-fuzzy models in the information-analytical system of prediction of forest fires. CEUR Workshop Proceedings, 2019, pp. 389-396.

16. Novak V., Perfil'eva I., Mochkorzh I. Matematicheskie printsipy nechetkoy logiki. [Mathematical Principles of Fuzzy Logic]. Moscow, Fizmatlit Publ., 2006. 352 p.

17. Sadatrasoul S., Gholamian M., Shahanaghi K. Combination of Feature Selection and Optimized Fuzzy Apriori Rules: The Case of Credit Scoring. The International Arab Journal of Information Technology, 2015, vol. 12, iss. 2, pp. 138-145. Available at: http://www.ccis2k.org/iajit/PDF/ vol.12,no.2/5795.pdf.

18. Mammadli S. [Fuzzy Sistema ocenki kreditov na osnove nechetkoj logiki]. Procedia Computer Science, 2016, vol. 102, pp. 495-499. (in Russ.) Available at: https://doi.org/10.1016/j.procs.

19. Shi J., Xu B. Credit Scoring by Fuzzy Support Vector Machines with a Novel Membership Function. Journal of Risk and Financial Management, 2016, vol. 9, iss. 4, pp. 1-10. DOI: $10.3390 / \mathrm{jrfm} 9040013$

20. Borisov V.V., Kruglov V.V., Fedulov A.S. Nechetkie modeli i seti Fuzzy models and network. [Fuzzy models and networks]. Moscow, Hot line - Telecom, 2007, 284 p.

Received 25 February 2021 


\title{
ПРИМЕНЕНИЕ НЕЧЕТКОЙ ЛОГИКИ ДЛЯ ОЦЕНКИ КРЕДИТНОГО РИСКА БАНКОВ
}

\author{
М.И. Озерова, И.Е. Жигалов \\ Владимирский государственный университет имени Александра Григорьевича \\ и Николая Григорьевича Столетовых, г. Владимир, Россия
}

\begin{abstract}
Банковская система является постоянно развивающейся системой. Информационная среда банка растет, увеличиваются объемы обрабатываемой информации из-за роста пользователей и банковских продуктов. Для сокращения рисков банки производят финансовую оценку положения физических и юридических лиц. Целью работы является разработка нечетких многосвязных моделей, предназначенных для прогнозирования получения положительного или отрицательного решения на получение банковского продукта. Решение принимается на основе скоринга. Скоринг заключается в присвоении баллов по заполнению некой анкеты, разработанной оценщиками кредитных рисков андеррайтерами. По результатам набранных баллов системой автоматически принимается решение об одобрении или отказе в выдаче кредита. Модели скоринга у разных банков различные. Цель исследования. Рассмотрено применение нечетких моделей для принятия решения банком на выдачу банковского продукта, реализующих концепцию «мягких вычислений». Методы. Применение методов нечеткой логики в кредитном скоринге не ново, но не имеет широкого применения на практике потому, что дорого обходится интеграция в существующие системы. Каждый банк применяет в скоринге свои показатели финансовой благонадежности клиента. Большая часть показателей в банках одинаковые, но при решении на выдачу разных банковских продуктов имеют различные числовые значения. В качестве исходных данных были взяты данные стандартной балльной методики реального банка. Для прогнозирования решения банка на выдачу клиенту банковского продукта была применена нечеткая модель, предложены продукционные правила, определены функции принадлежности. Модель ориентируема на одновременную обработку входящих данных от множества клиентов и для разных банков и различных скоринговых моделей. Результаты. Разработана математическая модель оценки рейтинга клиента и прогнозирования решения на получение банковского продукта на основе правила нечеткого вывода. Полученные результаты предложено использовать в мультибанковской веб-ориентированной системе предоставления корпоративным клиентам банковских продуктов.
\end{abstract}

Ключевые слова: математические модели, кредитный рейтинг, скоринг, нечеткие множества.

\section{Лuтература}

1. Ханнанова, Е.А. Теоретические основы оченки кредитоспособности / Е.А. Ханнанова // Вестник науки и образования. - 2016. - № 12 (24). - С. 46-48.

2. Костыкова, М.Ю. Скоринговая модель кредитования малого бизнеса и ее совершенствование в Российской Федераџии / М.Ю. Костыкова // Финансы и кредит. - 2014. - № 15. - С. 57-64.

3. A fuzzy decision support system for credit scoring / J. Ignatius, A. Hatami-Marbini, A. Rahman et al. // Neural Comput \& Applic, 2018, no. 29, pp. 921-937. DOI: 10.1007/s00521-016-2592-1

4. Горлушкина, Н.Н. Реинжиниринг бизнес-процесса кредитования и применение аппарата нечетких множеств для классификации заемщиков в задаче кредитного скоринга / Н.Н Горлушкина, Е.В. Шин // Интернет-журнал «Науковедение». Экономика и менеджмент. - 2015. - Т. 7, № 2. - C. 1-11. - https://naukovedenie.ru/PDF/82EVN215.pdf.

5. Derivation of descriptive and approximate fuzzy rules for credit scoring using evolutionary algorithms / F. Hoffmann, B. Basens, K. Mues et al. // European Journal of Operational Research. - 2007. P. 540-555.

6. Support system for fuzzy decisions for credit scoring / J. Ignatius, A. Khatami-Marbini, A. Rahman et al. // Neural calculations and applications. - 2016. - P. 1-17. DOI: 10.1007 / s00521-016-2592-1

7. Xinhui, C. On Consumer Credit Scoring Based on Multi-criteria Fuzzy Logic / C. Xinhui, Q. Zhong // Proc. Int. Conf. Business Intelligence and Financial Engineering, 2009, BIFE'09. - IEEE, 2009. - P. 765-768. 


\section{Управление в социально-экономических системах}

8. Lakhsasna, A. Modeling decisions on credit risk assessment using an optimized fuzzy classifier / A. Lakhsasna, R.N. Ainon, T.Yu. Vakh // International Symposium on Information Technology 2008. IEEE, 2008. - Vol. 1. - P. 2-8.

9. Кудинов, Ю.И. Разработка нечеткой системы прогнозирования качества металлопродукции / Ю.И. Кудинов, К.С. Иванченко, И.Ю. Кудинов // Мехатроника, автоматизация, управление. 2008. - № 10. - С. 27-32.

10. Лабинский, А.Ю. Использование нечеткой логики и нейронных сетей в системах автоматического управления / А.Ю. Лабинский, С.А. Нефедьев, Е.Н. Бардулин // Научно-аналитический журнал Вестник Санкт-Петербургского университета Государственной противопожарной службы МЧС России. - 2019. - № 1. - C. 44-50.

11. Pezeshki, Z. Comparison of artificial neural networks, fuzzy logic and neuro fuzzy for predicting optimization of building thermal consumption: a survey / Z. Pezeshki, S.M. Mazinani // Artif Intell. 2019. - Vol. 52, no. 1. - P. 495-525. DOI: 10.1007/s10462-018-9630-6

12. Xiaoying Su. Compound control system for coagulant dosing process based on a fuzzy cerebellar model articulation controller / Xiaoying Su, Sihong Xu, Shaochuan Xu // Conference: 2017 36th Chinese Control Conference (CCC). - IEEE, 2017. - P. 3931-3937. DOI: 10.23919/ChiCC.2017.8027972

13. Заде, Л. Понятие лингвистической переменной и его применение для принятия приближенных решений /Л. Заде. - М.: Мир, 1976. - 167 c.

14. Ярушкина, Н.Г. Интеллектуальный анализ временных рядов: учеб. пособие / Н.Г. Ярушкина, Т.В. Афанасьева, И.Г. Перфильева. - Ульяновск: УлГТУ, 2010. - 320 с.

15. Ozerova, M.I. Application of neuro-fuzzy models in the information-analytical system of prediction of forest fires / M.I. Ozerova, I.E. Zhigalov // CEUR Workshop Proceedings. - 2019. - P. 389-396.

16. Новак, В. Математические приниипы нечёткой логики / В. Новак, И. Перфильева, И. Мочкорж. - Физматлит. - 2006. - 352 с.

17. Sadatrasoul, S. Combination of Feature Selection and Optimized Fuzzy Apriori Rules: The Case of Credit Scoring / S. Sadatrasoul, M. Gholamian, K. Shahanaghi // The International Arab Journal of Information Technology. - 2015. - Vol. 12, iss. 2. - P. 138-145. - http://www.ccis2k.org/iajit/PDF/ vol.12,no.2/5795.pdf.

18. Mammadli, S. Fuzzy Logic Based Loan Evaluation System / S. Mammadli // Procedia Computer Science. - 2016. - Vol. 102. - P. 495-499. DOI: 10.1016/j.procs.2016.09.433

19. Shi, J. Credit Scoring by Fuzzy Support Vector Machines with a Novel Membership Function / J. Shi, B. Xu // Journal of Risk and Financial Management. - 2016. - Vol. 9, iss. 4. - P. 1-10. DOI: 10.3390/jrfm 9040013

20. Борисов, В.В. Нечеткие модели и сети / В.В. Борисов, В.В. Круглов, А.С. Федулов. - М.: Горячая линия-Телеком, 2007. - 284 c.

Озерова Марина Игоревна, канд. техн. наук, доцент кафедры информационных систем и программной инженерии, Владимирский государственный университет имени Александра Григорьевича и Николая Григорьевича Столетовых, г. Владимир; ozerovam@rambler.ru.

Жигалов Илья Евгеньевич, д-р техн. наук, профессор, заведующий кафедрой информационных систем и программной инженерии, Владимирский государственный университет имени Александра Григорьевича и Николая Григорьевича Столетовых, г. Владимир; ikgij@vlsu.ru.

Поступила в редакцию 25 февраля 2021 2.

\section{ОБРАЗЕЦ ЦИТИРОВАНИЯ}

Ozerova, M.I. Application of Fuzzy Logic to Assess Banks' Credit Risk / M.I. Ozerova, I.E. Zhigalov // Вестник ЮУрГУ. Серия «Компьютерные технологии, управление, радиоэлектроника». - 2021. - Т. 21, № 2. C. $70-78$. DOI: $10.14529 /$ ctcr210207

\section{FOR CITATION}

Ozerova M.I., Zhigalov I.E. Application of Fuzzy Logic to Assess Banks' Credit Risk. Bulletin of the South Ural State University. Ser. Computer Technologies, Automatic Control, Radio Electronics, 2021, vol. 21, no. 2, pp. $70-78$. DOI: $10.14529 /$ ctcr210207 